leder og to nestledere, en for Oslo universitetssykehus og en for Akershus universitetssykehus. Ved Oslo universitetssykehus er sykehus- og universitetslinjene likt organisert fra klinikknivå og nedover. Klinikkledere ved sykehuset har det samlede ansvar for all forsknings- og undervisningsaktivitet ved klinikken. Klinikklederne er direkte underlagt administrerende direktør $\mathrm{i}$ helseforetaket, men rapporterer gjennom bistilling ved Universitetet i Oslo også til instituttleder for Institutt for sykehusmedisin. Hvis klinikkleder ikke har akademisk bistilling, skal universitetets oppgaver ivaretas av forskningsleder ved den aktuelle klinikken. Hver klinikk skal nemlig ha en forskningsleder som er ansatt i en delt stilling ved Oslo universitetssykehus og universitetet. Oslo universitetssykehus har også opprettet et forskningsutvalg og et undervisningsutvalg der universitetet er representert. Forskningsutvalget skal fungere som et rådgivende organ for helseforetak og universitet.

Fakultetet har mer enn 700 vitenskapelig ansatte med arbeidsplass i Oslo universitetssykehus. Disse får nå en felles rapporteringslinje opp til klinikkledernivået. Før denne omorganiseringen hadde fakultetet ikke noe formelt nivå under fakultetdivisjonsleder. Dette kunne bety at noen fakultetdivisjonsledere kunne ha flere hundre ansatte som rapporterte direkte til seg. Dette var ingen god ordning verken for fakultetsleder eller for den enkelte ansatte. Det sier seg selv at det ikke var mulig å gjennomføre medarbeidersamtaler med så mange ansatte. Nå tror vi det skal være mulig å få dette til, fordi universitetets organisering innad i sykehuset for første gang vil nå helt ned til forskningsmiljøene og den enkelte universitetsansatte.

Petter Gjersvik har rett $i$ at den gamle ordningen, der professorer i full stilling også var sjef for Rikshospitalets avdelinger, er en saga blott. Dette var imidlertid slett ikke alltid noen god struktur for gjennomføring av forskning og undervisning, fordi fakultetet hadde for liten mulighet til å påvirke fagmiljøene og fordi universitetsfunksjonene for ofte ble nedprioritert $\mathrm{i}$ en krevende pasientrettet virksomhet. Med den nye organisasjonsstrukturen mener vi at både fakultetets og de universitetsansattes interesser blir bedre ivaretatt.

Erlend B. Smeland

Oslo universitetssykehus

Frode Vartdal

Finn Wisløff

Det medisinske fakultet

Universitetet i Oslo

\footnotetext{
Litteratur

1. Gjersvik P. Et fakultet styrt av klinikksjefer. Tidsskr Nor Legeforen 2009; 129: 2628-9.
}

\section{Ledelse og akademisk kompetanse}

I Tidsskriftet nr. 2/2010 ønsker Ola Didrik Saugstad seg tilbake til den tid da de vitenskapelig best kvalifiserte også hadde toppstillingene ved universitetssykehusene (1). Det kunne nok fungere den gang de formelle lederkravene, inkludert økonomi- og personalansvar, var betydelig mindre. Når nå klinikkene er på størrelse med middels store bedrifter, med 700-2 500 ansatte, vil det være altfor krevende både å være toppleder og i vitenskapsfronten. De fleste vil måtte velge hvor de vil sette inn hovedtyngden av sine personlige ressurser. Vi tror ikke det ville være riktig for våre toppforskere hvis de ved siden av krevende forskningsledelse skulle ta på seg den tunge belastningen det er å lede store klinikker. Ledergruppene i Oslo universitetssykehus skal imidlertid samlet ha betydelig vitenskapelig kompetanse. De nye forskningslederne i hver klinikk vil dessuten være viktige koordinatorer for forskningsaktiviteten og for samordning mellom Universitetet i Oslo og Oslo universitetssykehus.

Saugstads påstand om at fremskritt i norsk medisin og profilerte medisineres deltakelse i offentligheten forutsetter professor I-stillinger ved fakultetet, faller på sin egen urimelighet. Vi forstår heller ikke helt hva han mener når han hevder at fakultetets organisasjon vis-à-vis Oslo universitetssykehus representerer et ukontrollert medisinsk eksperiment som vil svekke den medisinske forskningen. Tvert imot: vi mener denne nye organisasjonsstrukturen vil muliggjøre en tettere integrasjon mellom fakultet og sykehus, til beste for både forskning og undervisning.

Samlet sett forvalter Universitetet i Oslo og Oslo universitetssykehus store ressurser og har et betydelig ansvar for medisinsk og helsefaglig forskning i Norge. Vi mener de endringene som nå er gjort ved Det medisinske fakultet og ved Oslo universitetssykehus samlet sett gir et meget godt grunnlag for å ivareta en ambisiøs målsetting om å styrke både universitet og helseforetak som forskningsinstitusjoner.

\section{Erlend B. Smeland}

Oslo universitetssykehus

\section{Frode Vartdal}

Finn Wisløff

Det medisinske fakultet

Universitetet i Oslo

\section{Litteratur}

1. Saugstad OD. Håndplukkede ledere betyr truet faglighet. Tidsskr Nor Legeforen 2010; 130: 133

\section{Misvisende om lederutnevning i Oslo universitetssykehus}

I Tidsskriftet nr. 2/2010 fremfører Ola Didrik Saugstad nok en gang tendensiøse opplysninger om hvordan ledere i Oslo universitetssykehus utnevnes (1). Saugstad konstaterer at dagens ledere er håndplukket av direktøren, og han er ikke i tvil om at det dreier seg om en kvalitetsreduksjon «fordi sjefer har en tendens til å ansette folk med lavere kompetansenivå enn dem selv». Det skulle vært interessant å se dokumentasjon for disse gufne og ubegrunnede påstandene. For kolleger som ikke kjenner ansettelsesprosedyrene i stillinger der stillingsinnehaveren har mer enn én arbeidsgiver, kan imidlertid Saugstads leserbrev etterlate inntrykk av at Det medisinske fakultet har abdisert fra å ansette sine egne professorer. Dette er selvsagt ikke tilfelle. I fortiden var det slik at avdelingssjefene ved Rikshospitalet satt i hovedstilling ved universitetet og bare i bistilling på sykehuset. Denne eiendommelige praksisen ville sykehuset naturlig nok ikke kontinuere, og for atskillige år tilbake meddelte Rikshospitalet fakultetsledelsen om at de ikke lenger ville tilsette klinikk- eller avdelingsledere som ikke i hovedstilling var ansatt ved sykehuset. Saugstad fremstiller det som en svakhet fra fakultetets side at de aksepterte dette. Jeg spør: hvilken moderne organisasjon ville akseptere at deres egne administrativt og økonomisk ansvarlige ledere hadde en annen hovedarbeidsgiver?

En helt annen sak er at så vel sykehus som fakultet hele tiden har vært bevisst på den gjensidige interessen de har av å finne et mest mulig sømløst samarbeid. Derfor satte fakultet og sykehus seg ned til omfattende forhandlinger som førte frem til en avtale der alle sider av samarbeidet er ivaretatt. En viktig del av avtalen er å sikre at de øverste lederne i bistilling har en bistilling ved fakultetet. Betydningen av dette for å sikre satsing på forskning og undervisning på alle plan burde ikke være nødvendig å begrunne nærmere. Forutsetningen for at en ellers kompetent leder kan bli professor, er selvsagt at vedkommende er kompetent til å inneha stillingen. Hovedregelen er at stillingene skal lyses ut som lederstilling og professor II samtidig. Har man søkt en slik stilling og er kompetent som professor, blir man tilsatt i professoratet. Er man ønsket i lederstillingen, men mangler professorkompetanse, blir man selvsagt ikke professor II. Så enkelt er det. Og bare for å presisere: Oslo universitetssykehus har naturlig nok ingen formell plass i ansettelsen av de mange kolleger som arbeider i stillinger ved sykehuset der universitetet er hovedarbeidsgiver. Hvis de eventuelt skal ansettes i en bistilling ved sykehuset, fungerer avtalen symmetrisk. Universitetet bestemmer hvem som skal ansettes og ved- 